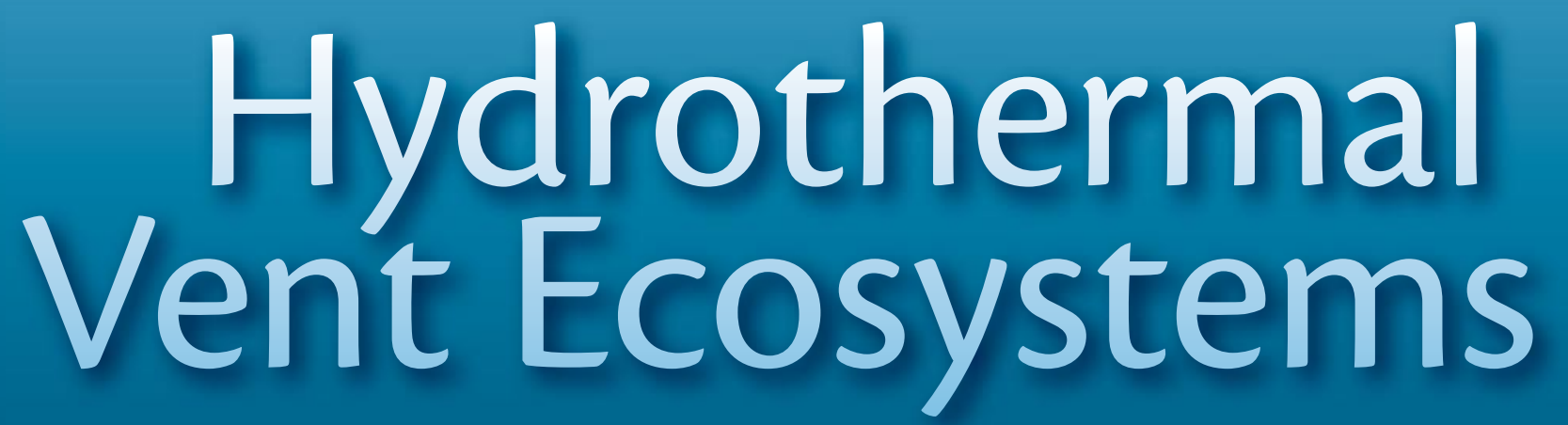

BY CHARLES R. FISHER,

KEN TAKAI, AND

NADINE LE BRIS

The analogy between hydrothermal vents and desert oases has been made many times since the discovery of the lush communities of animals that live around sites of active hydrothermal venting along oceanic spreading centers. Indeed, without the bacterial chemoautotrophic primary production that forms the basis of the food chain for these communities, the new seafloor would be even more barren than the older surrounding seafloor. Instead, one finds around the hydrothermal vents densities of animals with standing biomass as high as that of the most productive ecosystems on the planet (Figure 1).

Although the animals in these ecosystems require the oxygen that is produced by photosynthesis on Earth's surface, the rest of the energy fueling these communities comes from oxidation of the reduced chemicals dissolved in the acidic fluid venting from Earth's crust. Only microbes can harness that energy directly. The animal communities are therefore inextricably tied to microbes that can use geochemical energy to make organic compounds, and through them to the sources of that energy-hydrothermal fluids. In this review we discuss the fluid that fuels the ecosystems, followed by the physiological ecology of the microbes and animals that flourish in this extreme environment.

\section{HYDROTHERMAL FLUIDS}

The hydrothermal fluids emitted from spreading centers are formed well below the seafloor through the interaction of seawater and heated rocks or magma. The super-heated fluids are cooled rapidly when discharged at the seafloor, and many dissolved compounds precipitate out (Figure 2). This reaction forms hydrothermal chimneys, mineral edifices composed largely of iron, copper, and zinc sulfides. In most cases, the original (end-member) fluids mix with seawater during their transit up to the seafloor. However, the end-member fluid composition can be calculated from the composition of fluids emitted at the seafloor by extrapolating the concentration of conservative tracers present in seawater (such as magnesium) to zero. Appreciable variation among end-member fluids has been documented along a single ridge segment and even at a single vent at different times (Von Damm and Lilley, 2004). Nonetheless, most end-member fluids from spreading centers around the world share some common chemical features: they are anoxic, highly reduced, and acidic ( $\mathrm{pH}$ from 2-4), and are enriched in silica, carbon dioxide, hydrogen sulfide, methane, dihydrogen, iron, zinc, copper, and numerous other transition metals (Von Damm, 1995). The only known exception to this generalization is the recently discovered Lost City site, an off-axis hydrothermally active site of the Mid-Atlantic Ridge (Kelley et al., 2005). 
These fluids are thought to derive from a different process called serpentinization; they display very different characteristics with only moderately warm endmember temperatures (a maximum of $90^{\circ} \mathrm{C}$ ), alkaline $\mathrm{pH}$ (up to 10 ), and low- edifice as well as discrete sites of fluid emission with variable characteristics (Tivey, 2005). The chemistry of these more dilute, but still relatively hightemperature, hydrothermal fluids have not been studied in nearly the detail of

\section{The continued study of the life that inhabits}

these extreme environments will continue to yield insights and surprises that may change our preconceptions of life on Earth.

sulfide and high-hydrogen and methane contents (Kelley et al., 2005). It is likely that we will discover more sites like this as our exploration of spreading centers expands outward from the ridge axis.

Black-smoker fluids, emitted at or near end-member temperatures $\left(260-400^{\circ} \mathrm{C}\right)$, are abiotic — nothing can grow at these temperatures. However, a complex network of cracks, pipes, and porous materials channels the circulation of end-member fluid and seawater within and through the smoker wall to create a wide variety of habitable thermal regimes within and on the mineral

CHARLES R. FISHER (cfisher@psu.edu) is Professor, Department of Biology, The Pennsylvania State University, University Park, PA, USA. KEN TAKAI is Program Director, Extremobiosphere Research Center, Japan Agency for Marine-Earth Science and Technology, Yokosuka, Japan. NADINE LE BRIS is a research biochemist, Département Étude des Ecosystèmes Environnement Profonds, Ifremer, Plouzané, France. black-smoker fluids. However, the modeling work of Tivey (2005) indicates that various degrees of end-member mixing with seawater, conductive cooling or heating of fluids, and loss or enrichment in chemical elements during molecular diffusion through porous minerals can generate a broad range of chemical composition in these fluids. A wide diversity of bacteria can colonize the habitats bathed in fluids with temperatures below $150^{\circ} \mathrm{C}$, and animals often live in temperatures near $60^{\circ} \mathrm{C}$. The microbial activity can also have an impact on fluid properties within hydrothermal edifices; we are only beginning to study these phenomena directly (Nakagawa and Takai, 2006).

Metazoans (multicellular animals) often colonize the surfaces of hydrothermal chimneys. However, the highest-biomass assemblages of animals are usually found in areas of lowertemperature, diffuse flow (ambient to about $40^{\circ} \mathrm{C}$ ) emitted through cracks in the basalt or andesite substrate. Diffuse flow can occur over large areas of the seafloor on active spreading centers. These diffuse emissions were first thought to result primarily from subsurface dilution of high-temperature hydrothermal fluids. However, more recent comparisons of the chemistry of diffuse flow to the neighboring black-smoker fluids suggest the diffuse-flow chemistry reflects complex mixing dynamics, with input and removal of reactive chemical species. Iron and sulfide removal through mineral precipitation, along with sulfide and $\mathrm{CO}_{2}$ consumption, and methane production through microbial activity, can all have significant effects on these biologically important chemicals in diffuse-flow fluids before they exit the seafloor (Von Damm and Lilley, 2004). Furthermore, biological processes above the seafloor can have significant effects on the chemistry of habitats occupied by living organisms. For example, Johnson et al. (1994) demonstrated that sulfide consumption by biota within a community, such as a mussel bed, can lead to large deviations from a simple mixing model (of diffuse flow with ambient bottom water) within a single animal aggregation. Major deviations from simple mixing models are also found within the Pompeii worm (A. pompejana) habitat and have been attributed to conductive thermal exchange between fluids circulating inside and outside the worm tubes (Le Bris et al., 2005).

Even in a single aggregation of animals, where the variation in chemistry is well explained by simple mixing models, the microhabitats occupied by the animals are chemically and thermally heterogeneous on small temporal and spatial scales (Johnson et al., 1988b; Le Bris et al., 2006). The fluid bathing the mi- 
crohabitats can fluctuate over centimeters and seconds from water with the characteristics of the diffuse flow emitted from the seafloor to that of ambient deep-sea water (Johnson et al., 1988a, b). Temperatures may vary from $40^{\circ} \mathrm{C}$ to less than $2^{\circ} \mathrm{C}$, and concentrations of oxygen and other oxidized compounds present in seawater (such as nitrate and sulfate) vary from undetectable (anoxic) to ambient levels. Sulfide and reduced forms of other elements like $\mathrm{Fe}^{\mathrm{II}}$ present in diffuse flow decrease from concentrations as high as several hundreds of micromolar to undetectable, while $\mathrm{pH}$ increases from acidic values as low as 4 to slightly alkaline seawater ( 7.5 to 8 ) (Johnson et al., 1988b; Luther et al., 2001; Le Bris et al., 2006). Overlain on these gradients are changes in fluid emission correlated with tides and longer-period variations in deep-sea currents (Johnson et al., 1988a; Tivey et al., 2002). To live in this dynamic environment, much of the vent fauna must be well adapted to a range of environmental conditions.

A major biogeochemical consequence of the dynamic mixing of vent fluid and ambient water is the coexistence of chemical compounds that are mutually exclusive under conditions of chemical equilibrium. For example, sulfide and oxygen will react spontaneously to form more oxidized forms of sulfur (e.g., elemental sulfur $\mathrm{S}^{\circ}$, thiosulfate, polysulfides, or sulfate), leading to the total disappearance of the less abundant of the two reactants. However, in the mixing zone among most assemblages of vent fauna, both can be present at substantial micromolar levels. Chemical disequilibrium is, in fact, a general characteristic of the habitats occupied by vent animals and is sustained by the continual mixing of vent fluid with cold seawater. The energy liberated by the relaxation of these disequilibria provides the main energy input to the ecosystems.

\section{MICROBIAL ENVIRONMENTS AND ECOSYSTEMS}

The greatly varying chemical conditions present in different places above and below the seafloor at deep-sea hydrothermal vents, and the often very steep gradients between different conditions, generate a wide range of geochemical niches and potential energy sources for microorganisms. For example, chemolithoautotrophs are able to generate energy by exploiting the chemical disequilibria resulting from the relatively slow inorganic reaction kinetics of many redox reactions that can occur at the interface between oxidized seawater (containing $\mathrm{O}_{2}, \mathrm{NO}_{3}^{-}, \mathrm{Fe}^{3+}, \mathrm{SO}_{4}^{2-}$, and $\mathrm{CO}_{2}$ ) and reduced hydrothermal vent fluids (containing, for example, $\mathrm{H}_{2}, \mathrm{H}_{2} \mathrm{~S}, \mathrm{CH}_{4}$, $\mathrm{Fe}^{2+}$, and formate). While a range of novel chemolithotrophs have been isolated and cultured from deep-sea vents (see the recent review by Nakagawa and Takai, 2006), many chemolithotrophic organisms remain uncultured. In fact, it is likely that this group will include organisms that use rare or as yet never demonstrated redox couples to fuel their metabolism (Table 1). One of the more surprising recent microbial isolations from hydrothermal vents was a strictly anaerobic photoautotophic bacterium isolated from the $9^{\circ} 50^{\prime} \mathrm{N}$ field on the East Pacific Rise (Beatty et al., 2005). The ecological importance, abundance, and even capabilities of photoautotrophs in the light-starved, deep-sea hydrother- mal vent environment are still unclear, but the finding of this strict phototroph may "shed light" on the origin and early evolution of photosynthesis, which may even have occurred in the absence of sunlight at deep-sea hydrothermal vents.

The primary production by chemolithoautotrophs sustains not only the heterotrophic components in the microbial ecosystem but also the animal communities, either through symbioses or free-living bacteria that form the base of the food webs (Fisher et al., 1994). The pathways of inorganic carbon metabolism used for primary production by hydrothermal-vent microbes are very diverse, which may reflect the diversity of physical and chemical microhabitats they occupy. Although the well-known Calvin Benson cycle was assumed to be the dominant pathway of carbon fixation at vents, recent investigations suggest that the acetyl-CoA pathway, the modified Calvin cycle, the 3-hydroxypropionate pathway, and the reductive tricarboxylic acid (rTCA) cycle are all employed by various vent microbes from a variety of deep-sea hydrothermal habitats (see review by Takai et al., 2006).

Deep-sea hydrothermal vents also include some of the most physically and chemically challenging habitats on Earth for microbial growth (Takai et al., 2006). Since the first discovery of superheated hydrothermal vents called "black smokers" in 1979 at $21^{\circ} \mathrm{N}$ on the East Pacific Rise, microbiologists have been interested in empirically determining the upper temperature limit (UTL) for life as we know it, and research in this area has caught the interest of scientists from many disciplines as well as the general public. In 1989, a hyperther- 
mophilic, methane-producing archaeon, Methanopyrus kandleri, was isolated from the Guaymas Basin, which tied the previous UTL record of Pyrodictium occultum $\left(110^{\circ} \mathrm{C}\right)$ isolated from a shallow marine hydrothermal system (Huber et al., 1989). A few years later, the UTL was elevated to $113^{\circ} \mathrm{C}$ with the discovery of Pyrolobus fumarii at the Trans-Atlantic Geotraverse (TAG) hydrothermal field on the Mid-Atlantic Ridge (Blöchl et al., 1997). As the $3^{\circ} \mathrm{C}$ elevation of the
UTL took 14 years, many microbiologists believed that a temperature zone of $115-120^{\circ} \mathrm{C}$ was potentially the upper temperature for life. Then, in 2003, Kashefi and Lovely (2003) reported the isolation of hyperthermophilic archaeon

Table 1. Energetically favorable redox reactions available to chemolithotrophic microorganisms in the deep-sea hydrothermal vent environments.

\begin{tabular}{|c|c|c|c|c|c|}
\hline Energy Metabolisms & e- Donor & e- Acceptor & Redox Reaction & Identified & Cultured \\
\hline Methanotrophy & $\mathrm{CH}_{4}$ & $\mathrm{O}_{2}$ & $\mathrm{CH}_{4}+2 \mathrm{O}_{2}=\mathrm{CO}_{2}+2 \mathrm{H}_{2} \mathrm{O}$ & Yes & Yes \\
\hline Methanotrophy/sulfate reduction & $\mathrm{CH}_{4}$ & $\mathrm{SO}_{4}^{2-}$ & $\mathrm{CH}_{4}+\mathrm{SO}_{4}^{2-}=\mathrm{HCO}_{3}^{-}+\mathrm{HS}^{-}+\mathrm{H}_{2} \mathrm{O}$ & Yes & Not Yet \\
\hline Methanotrophy/denitrification & $\mathrm{CH}_{4}$ & $\mathrm{NO}_{3}^{-}$ & $\mathrm{CH}_{4}+2 \mathrm{NO}_{3}^{-}=\mathrm{HCO}_{3}^{-}+3 \mathrm{OH}^{-}+\mathrm{N}_{2}$ & No & No \\
\hline $\mathrm{H}_{2}$ oxidation/methanogenesis & $\mathrm{H}_{2}$ & $\mathrm{CO}_{2}$ & $\mathrm{H}_{2}+1 / 4 \mathrm{CO}_{2}=1 / 4 \mathrm{CH}_{4}+1 / 2 \mathrm{H}_{2} \mathrm{O}$ & Yes & Yes \\
\hline $\mathrm{H}_{2}$ oxidation/sulfate reduction & $\mathrm{H}_{2}$ & $\mathrm{SO}_{4}^{2-}$ & $\mathrm{H}_{2}+1 / 4 \mathrm{SO}_{4}^{2-}+1 / 2 \mathrm{H}^{+}=1 / 4 \mathrm{H}_{2} \mathrm{~S}+\mathrm{H}_{2} \mathrm{O}$ & Yes & Yes \\
\hline $\mathrm{H}_{2}$ oxidation/sulfur reduction & $\mathrm{H}_{2}$ & $\mathrm{~S}^{\circ}$ & $\mathrm{H}_{2}+\mathrm{S}^{\circ}=\mathrm{H}_{2} \mathrm{~S}$ & Yes & Yes \\
\hline S oxidation & $\mathrm{H}_{2} \mathrm{~S}$ & $\mathrm{O}_{2}$ & $\mathrm{H}_{2} \mathrm{~S}+2 \mathrm{O}_{2}=\mathrm{SO}_{4}^{2-}+2 \mathrm{H}^{+}$ & Yes & Yes \\
\hline S oxidation & $\mathrm{S}^{\circ}$ & $\mathrm{O}_{2}$ & $\mathrm{~S}^{\circ}+\mathrm{H}_{2} \mathrm{O}+31 / 5 \mathrm{O}_{2}=\mathrm{SO}_{4}^{2-}+2 \mathrm{H}^{+}$ & Yes & Yes \\
\hline S oxidation & $\mathrm{S}_{2} \mathrm{O}_{3}^{2-}$ & $\mathrm{O}_{2}$ & $\mathrm{~S}_{2} \mathrm{O}_{3}^{-}+10 \mathrm{OH}^{-}+\mathrm{O}_{2}+4 \mathrm{H}^{+}=2 \mathrm{SO}_{4}^{2-}+7 \mathrm{H}_{2} \mathrm{O}$ & Yes & Yes \\
\hline S oxidation/denitrification & $\mathrm{S}_{2} \mathrm{O}_{3}^{2-}$ & $\mathrm{NO}_{3}^{-}$ & $\begin{array}{c}\mathrm{S}_{2} \mathrm{O}_{3}^{-}+6 \mathrm{OH}^{+}+4 / 5 \mathrm{NO}_{3}^{-}+4 / 5 \mathrm{H}^{+}= \\
2 \mathrm{SO}_{4}^{-}+17 / 5 \mathrm{H}_{2} \mathrm{O}+2 / 5 \mathrm{~N}_{2}\end{array}$ & Yes & Yes \\
\hline S oxidation/denitrification & $\mathrm{S}^{\circ}$ & $\mathrm{NO}_{3}^{-}$ & $\begin{array}{c}\mathrm{S}^{\circ}+32 / 5 \mathrm{H}_{2} \mathrm{O}+6 / 5 \mathrm{NO}_{3}^{-}= \\
\mathrm{SO}_{4}^{2-}+34 / 5 \mathrm{H}^{+}+3 / 5 \mathrm{~N}_{2}+6 \mathrm{OH}^{-}\end{array}$ & Yes & Yes \\
\hline S oxidation/denitrification & $\mathrm{H}_{2} \mathrm{~S}$ & $\mathrm{NO}_{3}^{-}$ & $\begin{array}{c}\mathrm{H}_{2} \mathrm{~S}+36 / 5 \mathrm{H}_{2} \mathrm{O}+16 / 5 \mathrm{NO}_{3}^{-}= \\
2 \mathrm{SO}_{4}^{2-}+84 / 5 \mathrm{H}^{+}+8 / 5 \mathrm{~N}_{2}+16 \mathrm{OH}^{-}\end{array}$ & Yes & Yes \\
\hline $\mathrm{H}_{2}$ oxidation & $\mathrm{H}_{2}$ & $\mathrm{O}_{2}$ & $\mathrm{H}_{2}+1 / 2 \mathrm{O}_{2}=\mathrm{H}_{2} \mathrm{O}$ & Yes & Yes \\
\hline $\mathrm{H}_{2}$ oxidation/Fe reduction & $\mathrm{H}_{2}$ & $\mathrm{Fe}(\mathrm{III})$ & $\mathrm{H}_{2}+2 \mathrm{Fe}^{3+}=2 \mathrm{Fe}^{2+}+2 \mathrm{H}^{+}$ & Yes & Yes \\
\hline Fe oxidation & $\mathrm{Fe}(\mathrm{II})$ & $\mathrm{O}_{2}$ & $\mathrm{Fe}^{2+}+1 / 4 \mathrm{O}_{2}+\mathrm{H}^{+}=\mathrm{Fe}^{3+}+1 / 2 \mathrm{H}_{2} \mathrm{O}$ & Yes & Yes \\
\hline Fe oxidation/denitrification & $\mathrm{Fe}(\mathrm{II})$ & $\mathrm{NO}_{3}$ & $\begin{array}{c}\mathrm{Fe}^{2+}+1 / 5 \mathrm{NO}_{3}^{-}+2 / 5 \mathrm{H}_{2} \mathrm{O}+1 / 5 \mathrm{H}^{+}= \\
1 / 10 \mathrm{~N}_{2}+\mathrm{Fe}^{3+}+\mathrm{OH}^{-}\end{array}$ & Not Yet & Not Yet* \\
\hline Mn reduction & $\mathrm{H}_{2}$ & $\mathrm{MnO}_{2}$ & $\mathrm{H}_{2}+\mathrm{MnO}_{2}+2 \mathrm{H}^{+}=\mathrm{Mn}^{2+}+2 \mathrm{H}_{2} \mathrm{O}$ & Not Yet & Not Yet \\
\hline Nitrification & $\mathrm{NO}_{2}^{-}$ & $\mathrm{O}_{2}$ & $\mathrm{NO}_{2}^{-}+1 / 2 \mathrm{O}_{2}+2 \mathrm{OH}^{-}+2 \mathrm{H}^{+}=\mathrm{NO}_{3}^{-}+2 \mathrm{H}_{2} \mathrm{O}$ & Not Yet & Not Yet* \\
\hline Nitrification & $\mathrm{NH}_{3}$ & $\mathrm{O}_{2}$ & $\mathrm{NH}_{3}+3 \mathrm{OH}^{-}+\mathrm{O}_{2}=\mathrm{NO}_{2}^{-}+3 \mathrm{H}_{2} \mathrm{O}$ & Not Yet & Not Yet* \\
\hline $\mathrm{H}_{2}$ oxidation/denitrification & $\mathrm{H}_{2}$ & $\mathrm{NO}_{3}^{-}$ & $\begin{array}{c}\mathrm{H}_{2}+2 / 5 \mathrm{NO}_{3}^{-}+2 / 5 \mathrm{H}_{2} \mathrm{O}= \\
1 / 5 \mathrm{~N}_{2}+8 / 5 \mathrm{H}^{+}+2 \mathrm{OH}^{-}\end{array}$ & Yes & Yes \\
\hline
\end{tabular}

*Potential microbial components have been detected but the metabolic pathways are not yet fully described 
strain 121 from the Juan de Fuca Ridge (Northeast Pacific Ocean), growing at temperatures up to $121^{\circ} \mathrm{C}$, which is still the highest growth temperature (UTL) documented for microbial life. However, one must always keep in mind that only a tiny fraction of the microbes collected have been cultured; the so far unculturable majority will certainly include some with new and unexpected physiological abilities and tolerances.

An unresolved paradox exists between the empirically determined exposure temperatures that hydrothermal vent microbes can withstand in the laboratory and the temperatures of fluids from which they are isolated. Although several strains can survive exposure to temperatures slightly above their growth (UTL) temperatures for limited times, none can survive experimental exposure to temperatures approaching what they are likely exposed to in the vent environment. The current record holder for high-temperature exposure is hyperthermophilic archaeon strain 121 , which can only survive exposure up to $130^{\circ} \mathrm{C}$ for 120 minutes (under 0.3 MPa) (Kashefi and Lovely, 2003). In contrast, viable hyperthermophiles have often been cultured from samples of superheated $\left(>250^{\circ} \mathrm{C}\right)$ hydrothermal fluids or materials (e.g., Takai et al., 2004). It is likely that these organisms are at least exposed to this extreme high temperature, because the most parsimonious explanation for their occurrence in the samples is that the microbes were entrained by the superheated hydrothermal fluids from their natural habitat in the subvent biosphere (Takai et al., 2004). One example is the hyperthermophilic archaeon (Thermoccus sp. strain Tc-1-95) isolated

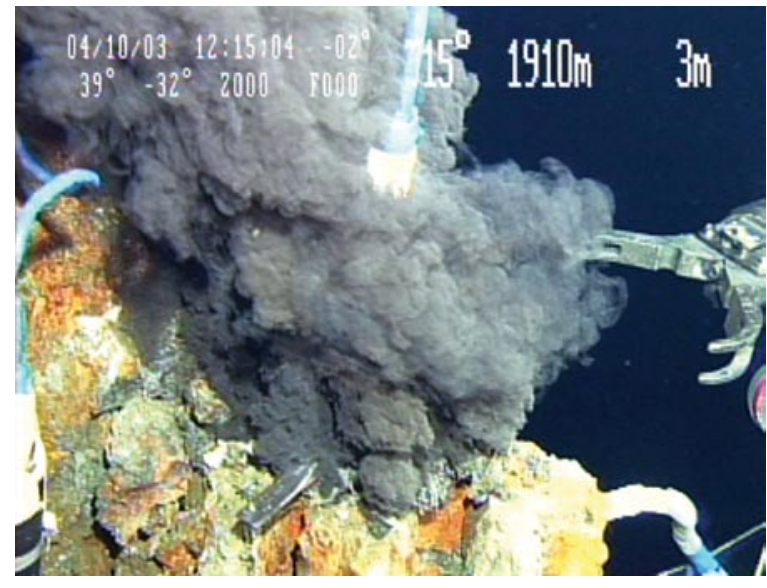

Figure 3. The JAMSTEC microbial in situ colonization system deployed in a smoker in the Mariner vent field in the Lau back-arc basin. Photo courtesy of K. Takai and JAMSTEC

from an in situ colonization system deployed at a $>250^{\circ} \mathrm{C}$ black smoker vent in the Central Indian Ridge Kairei field. It was one of the dominant microbial populations recovered from the in situ colonization system (Figure 3), but did not survive even brief exposure to $120^{\circ} \mathrm{C}$ under in situ hydrostatic pressure in the laboratory (Mitsuzawa et al., 2005). Although this experiment was conducted at in situ hydrostatic pressure, other characteristics of the deep-sea hydrothermal vent microbial habitat were not present in the experimental system. The physical interactions between minerals and microbial cells and the dissolved gas components of hydrothermal fluids may all be significant factors affecting the thermal survival limits of hydrothermal vent hyperthermophiles.

\section{METAZOAN ENVIRONMENTS AND ECOSYSTEMS}

Animals, in part as a result of the constraints imposed by their larger size, more complex bodies, and more limited metabolic repertoire, are much more restricted with respect to the vent microhabitats they can occupy. For example, despite occasional reports in the literature, there are no commonly accepted examples of metazoans (multicellular animals) that can live their entire lives without oxygen (anaerobically). However, many animals can live for extended periods anaerobically, and many can also take up oxygen from very low external concentrations. Although there is abundant oxygen in the ambient bottom water over most hydrothermal vents, many of the microhabitats occupied by animals at vents contain little or no oxygen most of the time. To facilitate survival in these low-oxygen habitats, the majority of the larger animals have oxygenbinding proteins with much higher affinities for oxygen than their close relatives from more benign environments (for a review, see Hourdez and Lallier, 2006). These proteins include the hemoglobins present in symbiont-containing groups like the siboglinid "giant" tubeworms and vesicomyid clams, as well as hemoglobins in other worms like the bright- 
red polynoid scale worms (Figure 4)

found at vents all over the world, and the blue hemocyanins present in many vent crabs. As a result, although animals are very unlikely to be found in habitats without at least occasional access to oxygen, many vent animals thrive in habitats with very low levels of oxygen and with intermittent exposure to oxygen (Childress and Fisher, 1992).

Similarly, metazoans are much more restricted with respect to temperature tolerance than microbes. The steep gradients of the more extreme vent habitats make this very difficult to analyze in situ, as was demonstrated beautifully by a video frame grab of an alvinellid worm (Alvinella pompejana from the East Pacific Rise) curled around the DSV Alvin temperature probe while its reading of $105^{\circ} \mathrm{C}$ is displayed on the monitor (Chelvadonne et al., 1992). These

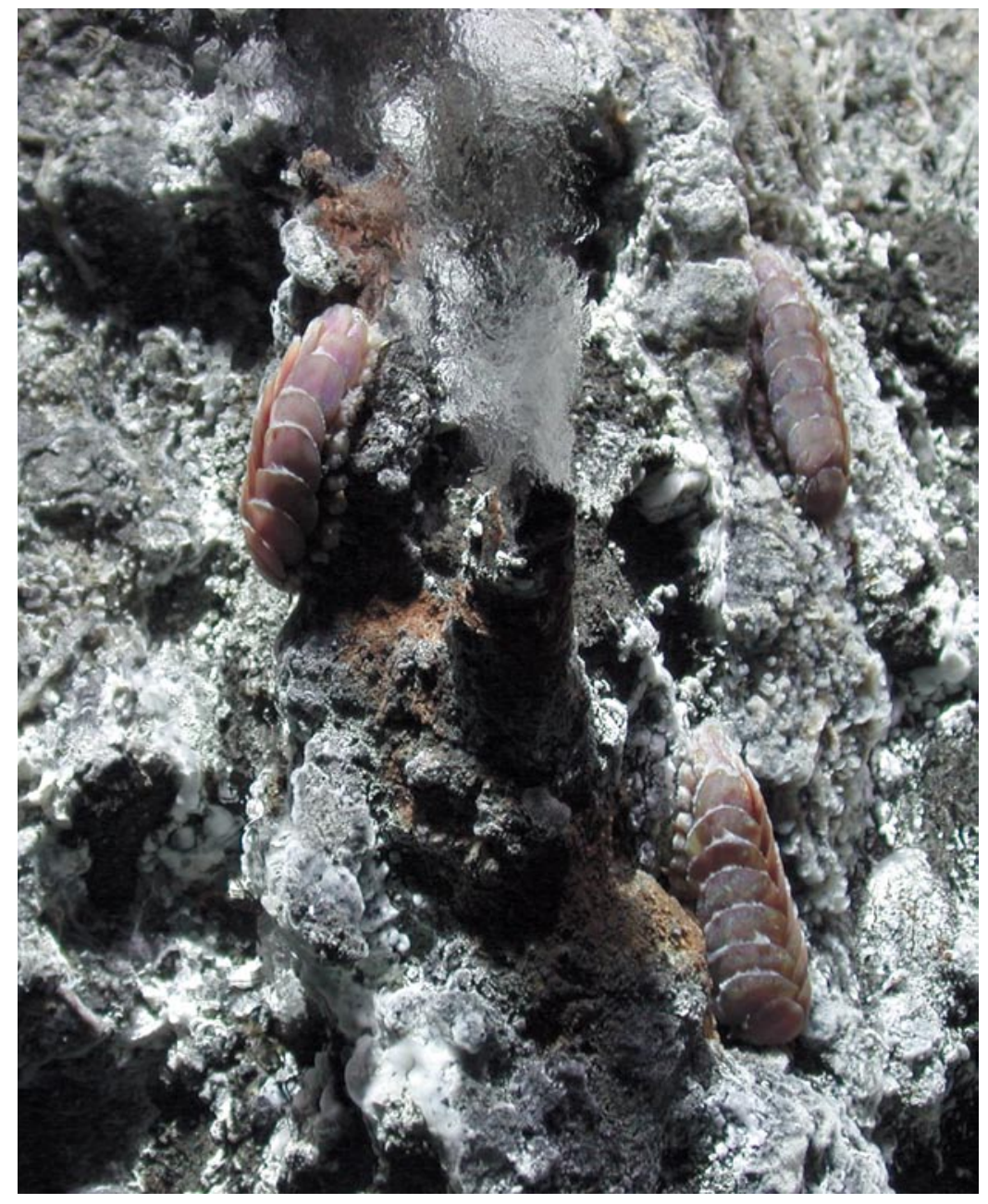

Figure 4. Polynoid scale worms (Branchinotogluma sezonzaci) on a smoker wall in the ABE vent field of the East Lau Basin Spreading Center. Their red color is from the hemoglobin in this active vent predator. Photo courtesy of the Ridge 2000 program extreme gradients were also evident in later measurements of the habitat temperatures of this chimney dweller (Cary et al., 1998). Temperatures on the mineral substrate beneath worm colonies have been reported up to $127^{\circ} \mathrm{C}$ and even $175^{\circ} \mathrm{C}$, along with much more moderate conditions of $6^{\circ} \mathrm{C}$ to $45^{\circ} \mathrm{C}$ around the outer openings of the animal tubes (reviewed in Le Bris and Gaill, in press). Recently, Le Bris et al. (2005) used a pH electrode coupled with a temperature probe to determine when their probes penetrated the fragile alvinellid tubes (and encountered higher temperatures). The $\mathrm{pH}$ of the fluids inside the tubes was close to that of $10^{\circ} \mathrm{C}$ diffuse flow, suggesting that in unbroken tubes, conductive heating rather than direct exposure to hotter vent fluid dominates. The highest temperature they recorded within alvinellid tubes, under conditions when leakage through the wall of the alvinellid tubes could be rejected, was $55^{\circ} \mathrm{C}$. These measurements support a variety of physiological data on the temperature tolerance of the animal's tissues (reviewed in Chevaldonné et al., 2000), although empirical demonstration of the thermal tolerance of this species must await experiments in high-pressure aquaria. This milestone was recently achieved for its northern Pacific relative, Paralvinella sulfincola, which inhabits the highesttemperature environments of any of the Northeast Pacific chimney fauna (Figure 5). Girguis and Lee (2006) demonstrated that $P$. sulfincola tolerates body temperatures between $50^{\circ}$ and $55^{\circ} \mathrm{C}$, the highest demonstrated for a marine metazoan. By providing a temperature gradient in their high-pressure aquaria, the authors were also able to demon- 
strate that the worms actually preferred temperatures in the range $40^{\circ} \mathrm{C}$ to $50^{\circ} \mathrm{C}$, well above the temperatures that most marine animals can tolerate.

Equally extreme and challenging aspects of the vent environment that animals have adapted to are the thermal gradients, both in space and in time. Animals like the chimney dwellers described above live in an environment where one end of their bodies can be exposed to waters near $60^{\circ} \mathrm{C}$ while the other end is in water below $10^{\circ} \mathrm{C}$, sometimes even in the ambient deep-sea temperatures near $2^{\circ} \mathrm{C}$ (reviewed in Le Bris and Gaill, in press). These relatively small worms are quite mobile, so they can quickly move away from hot water to thermoregulate or migrate to a new location and secrete a new tube. Adult hydrothermal vent siboglinid tubeworms, on the other hand, live anchored in one place as adults. In the case of the giant tubeworm, Riftia pachyptila, that habitat can span a temperature range of up to $30^{\circ} \mathrm{C}$ from the base, where it is attached near a source of diffuse flow, to the plume, up to a meter away in water that is often near ambient temperatures. Furthermore, this is not a static environment, as the temperature near the plume can vary by up to $15^{\circ} \mathrm{C}$ in seconds (Johnson et al., 1988a). These gradients must present significant physiological challenges to metazoans, which must maintain physiological homeostasis, while many molecules and processes are drastically affected by temperature over this range. Imagine living with your feet constantly bathed in very warm water, while your head was immersed in ice water.

Another aspect of the vent environment that requires special adaptations of the hydrothermal vent fauna is the toxicity of the hydrothermal fluid (see Childress and Fisher 1992 for a review). Not only is hydrothermal fluid often loaded with heavy metals and the environment enriched in radioactive elements, but hydrogen sulfide is also often present at levels that are 10 to 100 times higher than concentrations that are toxic to most metazoans. All animals require food, and at hydrothermal vents the food is produced by chemoautotrophic bacteria exposed to vent fluid. For most vent animals this means that they must tolerate significant exposure to that fluid, as they either graze on bacteria attached to surfaces in their habitat or filter bacteria out of the vent effluent bathing them. Even the predatory vent fauna, like the vent fish, octopuses, and scale worms (Figure 5), must at least occasionally venture into vent fluid to catch and eat

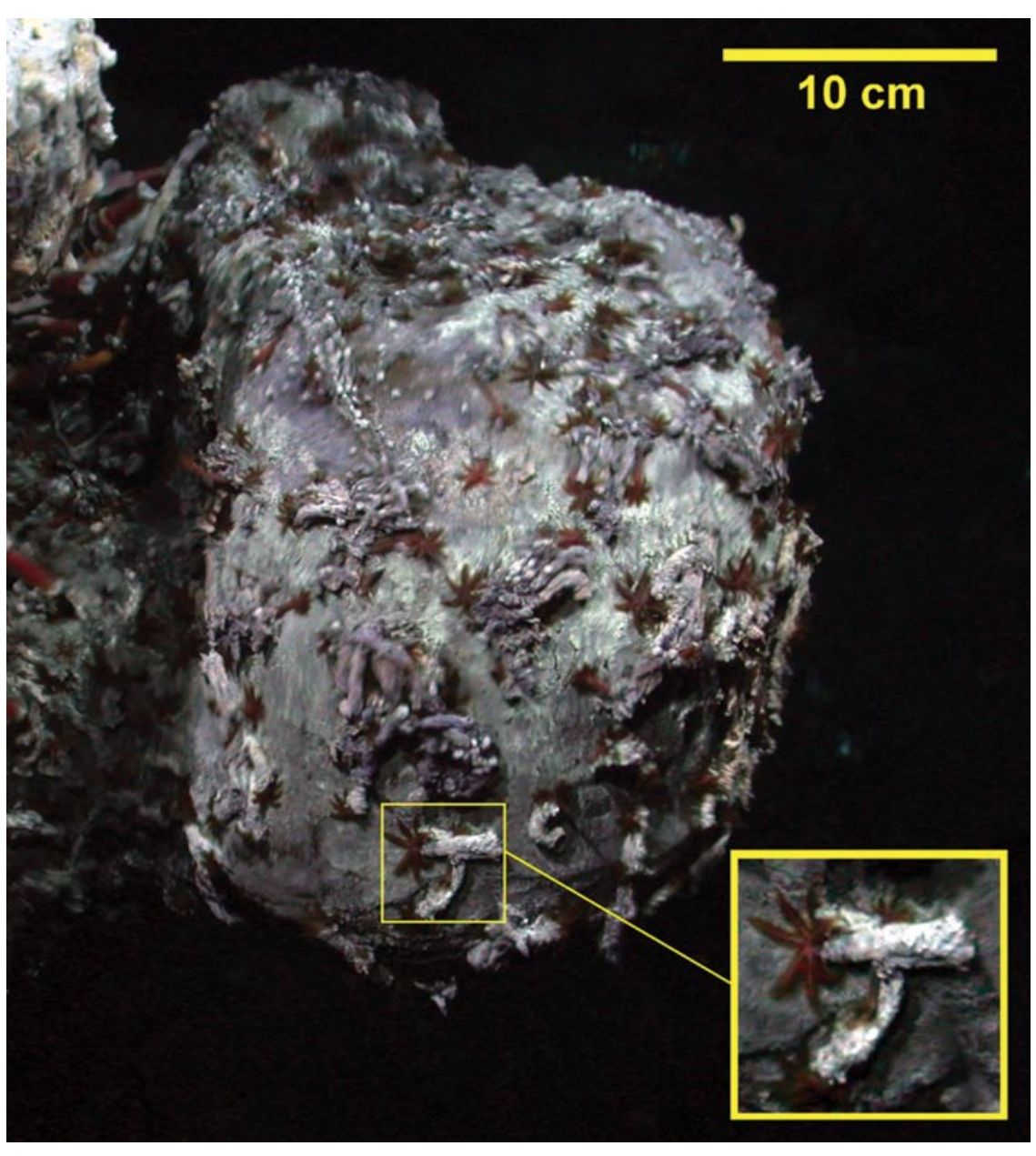

Figure 5. The current empirically confirmed hydrothermal vent animal record holder for thermal tolerance, Paralvinella sulfinicola, on the wall of a smoker in the Main Endeavour vent field on the Juan de Fuca Ridge, Northeast Pacific Ocean. Photo courtesy of P. Girguis and MBARI 
their prey. However, the vent animals that dominate the biomass of the communities at most vent sites have gone a step further and harbor the bacteria that produce their food, either in or on their bodies. These organisms are actually symbiotic associations of chemoautotrophic microbes and an animal host. Animals like the siboglinid tubeworms have completely lost the ability to feed by normal means as adults, and have no mouth, gut, or anus. Instead, they harbor tens to hundreds of billions of symbionts in their bodies contained by specialized cells inside a unique organ, the trophosome. To supply their internal symbionts with both oxygen and the sulfide they require, tubeworms have evolved special hemoglobins that bind both molecules $\left(\mathrm{O}_{2}\right.$ and $\left.\mathrm{HS}^{-}\right)$reversibly, but with very high affinity (Arp et al., 1985). This mechanism allows them to transport high concentrations of sulfide through their bodies without experiencing the toxic effects of the sulfide, and still provide the symbionts with a chemical environment that "free living [chemoautotrophic] bacteria can only regard with envy" (Fisher et al., 1988). Other animals, like the bathymodiolin mussels that are found on almost every ridge system we know of, and the giant snails of the Indian Ocean and western Pacific (Figure 1), harbor their symbionts in their gills. Yet others, like the shrimp of the Mid-Atlantic Ridge and the bar-

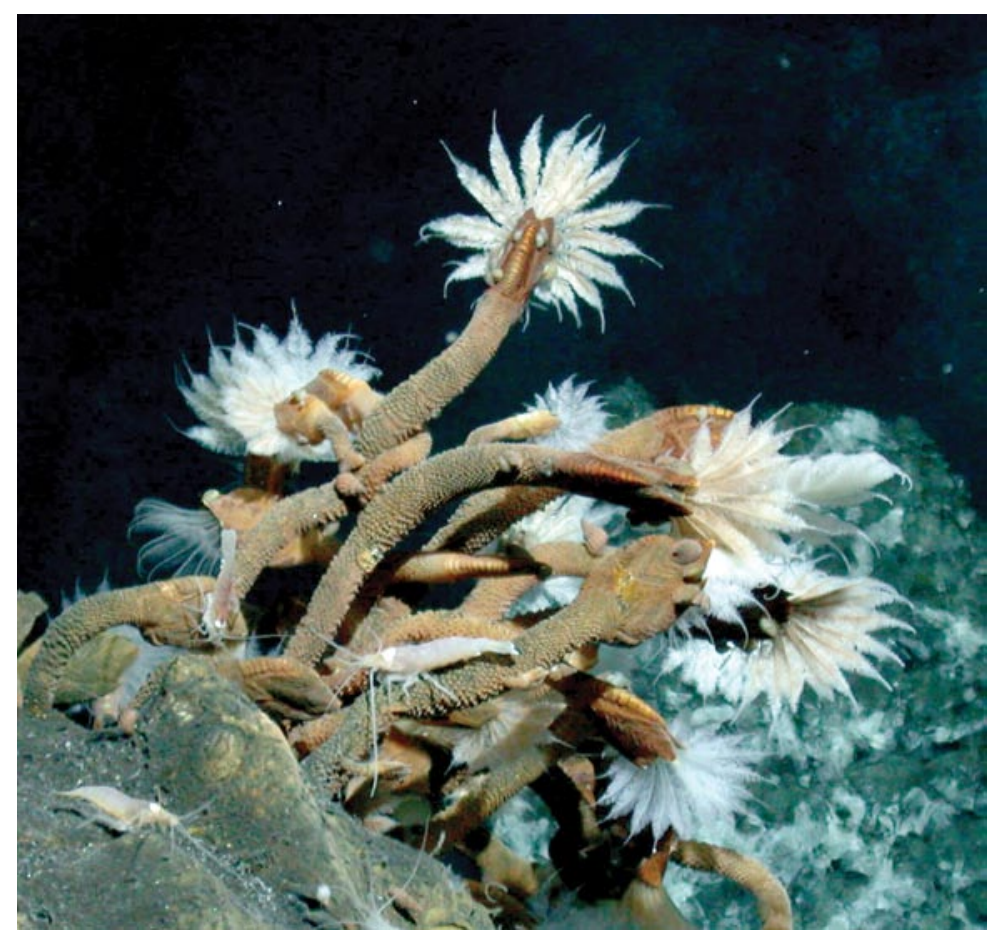

Figure 6. The white color of the featherlike cirri of this Lau Basin barnacle (Vulcanolepas sp.) is due to the presence of symbiotic chemoautotrophic bacteria. Photo courtesy of the Ridge 2000 program

nacles of the western Pacific (Figure 6), harbor their symbionts on the surfaces of their bodies.

Although habitats with relatively high and variable temperature, and highsulfide and low-oxygen concentrations present the biggest challenge to evolutionary invasion, these are also the habitats with the highest potential rewards for the fauna that can adapt to them. These are the areas where chemoautotrophic bacteria will thrive, producing a rich food source, and also the areas where predation pressure may be the least (as predators must also be specially adapted to tolerate these habitats, and remarkably few appear to have evolved these adaptations). Because chemoautotrophic bacteria can thrive at extremes that animals cannot tolerate, it should come as no surprise that hydrothermal vent fauna have evolved to push the limits of metazoan tolerance to oxygen, temperature, and sulfide.

\section{LOOKING FORWARD}

The first deep-sea hydrothermal vent ecosystem was discovered a mere 30 years ago and some key aspects of even the best-studied animals are not well understood. Work on most of the other known vent species has not progressed much beyond their taxonomic description and/or placement in phylogenetic trees. New vent species are still being described at a rate of nearly two per month, and new vents (even new types of vents) are still being discovered and explored. Entire ridges have yet to be visited by submersible, and entirely new biogeographic provinces and perhaps types of animals and communities may await discovery on more remote spread- 
ing centers. The continued study of the life that inhabits these extreme environments will continue to yield insights and surprises that may change our preconceptions of life on Earth.

\section{ACKNOWLEDGEMENTS}

The information reviewed in this article could not have been obtained without international collaboration among scientists and sharing of national deepsubmergence assets and the expertise of those that operate them. The authors express their gratitude to the ship captains and crews of the InterRidge community, and the operators, pilots, navigators, and support personnel of the manned research submersibles and remotely operated vehicles that make in situ sampling and experimentation at deep-sea hydrothermal vents possible. 四

\section{REFERENCES}

Arp, A.J., J.J. Childress, and C.R. Fisher. 1985. Blood gas transport in Riftia pachyptila. Bulletin of the Biological Society of Washington 6:289-300.

Beatty, J.T., J. Overmann, M.T. Lince, A.K. Manske, A.S. Lang, R.E. Blankenship, C.L. Van Dover, T.A. Martinson, and F.G. Plumley. 2005. An obligately photosynthetic bacterial anaerobe from a deep-sea hydrothermal vent. Proceedings of the National Academy of Sciences USA 102:9,306-9,310.

Blöchl, E., R. Rachel, S. Burgraff, D. Hafenbradl, H.W. Jannasch, and K.O. Stetter. 1997. Pyrolobus fumarii, gen. and sp. nov., represents a novel group of archaea, extending the upper temperature limit for life to $113^{\circ} \mathrm{C}$. Extremophiles 1:14-21.

Cary, S.C., T. Shank, and J. Stein. 1998. Worms bask in extreme temperatures. Nature 391:545-546.

Chelvadonné, P., D. Desbruyères, and J.J. Childress. 1992. Some like it hot... and some even hotter. Nature 359:593-594.

Chevaldonné, P., C.R. Fisher, J.J. Childress, D. Desbruyères, D. Jollivet, F. Zal, and A. Toulmond. 2000. Thermotolerance and the 'Pompeii worms.' Marine Ecology Progress Series 208:293-295.

Childress, J.J., and C.R. Fisher. 1992. The biology of hydrothermal vent animals: physiology, bio- chemistry and autotrophic symbioses. Oceanography and Marine Biology 30:337-441.

Fisher, C.R., J.J. Childress, S.A. Macko, and J.M. Brooks. 1994. Nutritional interactions at Galapagos hydrothermal vents: inferences from stable carbon and nitrogen isotopes. Marine Ecology Progress Series 103:45-55.

Fisher, C.R., J.J. Childress, and N.K. Sanders. 1988. The role of vestimentiferan hemoglobin in providing an environment suitable for chemoautotrophic sulfide oxidizing endosymbionts. Symbiosis 5:229-246.

Girguis, P.R., and R.W. Lee. 2006. Thermal preference and tolerance of alvinellids. Science 312:231.

Hourdez, S., and F.H. Lallier. 2006. Adaptations to hypoxia in hydrothermal-vent and cold-seep invertebrates. Reviews in Environmental Science and Biotechnology doi: 10.1007/s11157-0069110-3.

Huber, R., M. Kurr, H.W. Jannasch, and K.O. Stetter. 1989. A novel group of abyssal methanogenic archaebacteria (Methanopyrus) growing at $110^{\circ} \mathrm{C}$. Nature $342: 833-834$.

Johnson, K.S., J.J. Childress, and C.L. Beehler. 1988a. Short time temperature variability in the Rose Garden hydrothermal vent field: An unstable deep-sea environment. Deep-Sea Research I 35:1,711-1,721.

Johnson, K.S., J.J. Childress, R.R. Hessler, C.L. Sakamoto-Arnold, and C.L. Beehler. 1988b. Chemical and biological interactions in the Rose Garden hydrothermal vent field, Galapagos spreading center. Deep-Sea Research I 35:1,723-1,744.

Johnson, K.S., J.J. Childress, C.L. Beehler, and C.L. Sakamoto-Arnold. 1994. Biogeochemistry of hydrothermal vent mussel communities: The deep sea analogue to the intertidal zone. DeepSea Research I 41:993-1,011.

Kashefi, K., and D.R. Lovley. 2003. Extending the upper temperature limit for life. Science 301:934.

Kelley, D.S., J.A. Karson, G.L. Früh-Green, D.R. Yoerger, T.M. Shank, D.A. Butterfield, J.M. Hayes, M.O. Schrenk, E.J. Olson, G. Proskurowski, M. Jakuba, A. Bradley, B. Larson, K. Ludwig, D. Glickson, K. Buckman, A.S. Bradley, W.J. Brazelton, K. Roe, M.J. Elend, A. Delacour, S.M. Bernasconi, M.D. Lilley, J.A. Baross, R.E. Summons, and S.P. Sylva. 2005. A serpentinite-hosted ecosystem: The Lost City hydrothermal field. Science 307:1,428-1,434.

Le Bris, N., M. Zbinden, and F. Gaill. 2005. Processes controlling the physico-chemical microenvironments associated with Pompeii worms. Deep-Sea Research I 52:1,071-1,083.

Le Bris, N., B. Govenar, C. Le Gall, and C.R. Fisher. 2006. Variability of physico-chemical conditions in $9^{\circ} \mathrm{N}$ EPR diffuse flow vent habitat. Marine Chemistry 98:167-182.

Le Bris, N., and F. Gaill. 2006. How does the an- nelid Alvinella pompejana deal with an extreme hydrothermal environment? Reviews in Environmental Science and Biotechnology doi: 10.1007/s11157-006-9112-1.

Luther, G.W., III, T.F. Rozan, M. Taillefert, D.B. Nuzzio, C. Di Meo, T.M. Shank, R.A. Lutz, and S.C. Cary. 2001. Chemical speciation drives hydrothermal vent ecology. Nature 410:813-816.

Mitsuzawa, S., S. Deguchi, K. Takai, K. Tsujii, and K. Horikoshi. 2005. Flow-type apparatus for studying thermotolerance of hyperthermophiles under conditions simulating hydrothermal vent circulation. Deep-Sea Research I 52:1,085-1,092.

Nakagawa, S., and K. Takai. 2006. The isolation of thermophiles from deep-sea hydrothermal environments. Methods in Microbiology 35:55-91.

Takai, K., T. Gamo, U. Tsunogai, N. Nakayama, H. Hirayama, K.H. Nealson, and K. Horikoshi. 2004. Geochemical and microbiological evidence for a hydrogen-based, hyperthermophilic subsurface lithoautotrophic microbial ecosystem (HyperSLiME) beneath an active deep-sea hydrothermal field. Extremophiles 8:269-282.

Takai, K., S. Nakagawa, A.-L. Reysenbach, and J. Hoek. 2006. Microbial ecology of mid-ocean ridges and back-arc basins. Pp. 185-214 in Interpretations among Physical, Chemical, Biological, and Geological Processes in Back-Arc Spreading Systems. D. Christie, C.R. Fisher, S.-M.

Lee, and S. Givens, eds, American Geophysical Union, Washington, DC.

Tivey, M.K., A.M. Bradley, T.M. Joyce, and D. Kadko. 2002. Insights into tide-related variability at seafloor hydrothermal vents from time-series temperature measurements. Earth and Planetary Science Letters 202:693-707.

Tivey, M.K. 2005. Environmental conditions within active seafloor vent structures: Sensitivity to vent fluid composition and fluid flow. Pp. 137-152 in Subseafloor Biosphere at Mid-Ocean Ridges. W.S.D. Wilcock, E.F. DeLong, D.S. Kelley, J.A. Baross, and S.C. Cary, eds, American Geophysical Union, Washington, DC.

Von Damm, K.L. 1995. Controls on the chemistry and temporal variability of seafloor hydrothermal fluids. Pp. 222-247 in Seafloor Hydrothermal Systems: Physical, Chemical, Biological and Geological Interactions. S.E. Humphris, R.A. Zierenberg, L.S. Mullineaux, and R.E. Thomson, eds, American Geophysical Union, Washington, DC.

Von Damm, K.L., and M.D. Lilley. 2004. Diffuse flow hydrothermal fluids from $9^{\circ} 50^{\prime} \mathrm{N}$ East Pacific Rise: Origin, evolution and biogeochemical controls. Pp. 245-268 in Subseafloor Biosphere at Mid-Ocean Ridges. W.S.D. Wilcock, E.F. DeLong, D.S. Kelley, J.A. Baross, and S.C. Cary, eds, American Geophysical Union, Washington, DC. 